\title{
Search in Criminal Procedure of Russia and Germany: Comparative Legal Characteristics
}

\author{
Anton Shamne* \\ Volgograd State University, 400062, Prosp. Universitetsky, 100, Volgograd, Russia, antonsh97@gmail.com
}

\begin{abstract}
The article compares the Criminal Procedural Codes provisions of the Russian Federation and the Federal Republic of Germany that regulate conducting a search as an investigative act. It also provides and compares the definitions of the concept "search" and "dwelling" given in Russian and German criminal procedural legislation. The reasons for conducting the search in general and the search of dwelling are considered, similarities and differences are revealed in relation to the status of the subject who is under the search. The author characterizes the search of dwelling and gives a comparative analysis of this investigative action as well as the notion of "urgent cases" in both countries. The authors also proposed some brief recommendations for improving the norms of the Russian Federation Criminal Procedure Code.
\end{abstract}

\section{Introduction}

In the modern period of development of the state and society, the main value of both Russian and European states is the person, personality, one's rights and freedoms, which are appropriately reflected in the legislation. So, the Constitution in Chapter 2 keeps the rights and freedoms of a person and a citizen which are protected by the state. In the legal community, of course, the main emphasis should be made strictly on the proclamation of a number of fundamental rights and freedoms of a person, their observance and protection. It especially concerns such rights as personal privacy and inviolability of dwelling, personal and family secrets, protection of one's honour and good name (article 23, 25 of the Constitution of the Russian Federation), etc.

However, as it was rightly pointed out by A.V. Smirnov that the science of the criminal procedure is internationalized. And although it develops in different countries where there are different orders of the criminal procedures, its principal legal institutions often have a common origin and similar content. Therefore, the achievements of legal thought and legislation in other states, foreign companies and institutions can successfully be seen on the domestic market and need studying, as well as the existing disadvantages [1].

It is well known that any state by virtue of its authority may restrict rights and freedoms of a human and a citizen, but only in the cases prescribed by the law. This restriction is only possible with the purpose to protect the interests of the state, society or individual.

In the framework of the research, it seems relevant to consider the question of the essence and procedure of holding investigative actions such as a search which, of course, affects important personal interests of the individual. Prominent Russian lawyer and brilliant forensic orator A.F. Koni in one of his speeches noted that searches "to such an extent bring confusion in private lives of people and attitudes of surrounding people that they should be held with special care" [2].

\section{Approaches to the consideration of the concept "search"}

The legal concept "search" is enshrined in the criminal procedure codes of many states because of its importance and relevance in the criminal process. And here we may note the opinion by the L.V. Maiorova reasonably believing that many provisions of the Russian Federation Code of Criminal Procedure (RFCCP) require clarification and some rethinking. Therefore, the study of foreign experience, recourse to the comparative law contributes to harmonization and unification of norms in the domestic law, affects the content of both theory and practice [3], [4].

In this regard, it seems appropriate to give a comparative legal characteristic of the search concept in relation to the criminal process of Russia and Germany, since, after the Second World War, Germany accumulated considerable experience in the field of protecting rights and freedoms of a human and a citizen. The article focuses on the specific aspects of the search essence and its holding in relation to the search of dwelling to establish similarities and differences in the criminal process of the states named.

A renowned expert in the field of Russian criminal process, S.A. Schaefer, gives the following definition of a search: "the search is based on observation and includes compulsory inspection of premises, dwellings and other places, individual citizens carried out in

\footnotetext{
* Corresponding author: antonsh97@ gmail.com
} 
accordance with the procedure prescribed by the law to find and seize physical evidence, relevant documents and values, as well as wanted persons and bodies" [5]. Part 2, article 29 of the RFCCP determines that only the court is competent to make the decision on the search of dwelling.

The code of criminal procedure of FRG does not determine a search. An appeal to the relevant legal literature allows speaking about the current generalized approach to this concept. So, V. Beulke writes: "A search is looking for people, evidence, and objects that are subject to seizure. The object of the search may become apartments, other premises (including a search in the apartment), movable things, and people themselves. Depending on the person who undergoes the search warrant (a suspect or someone else), there are allocated special requirements for the legality of the search" [6].

It should be emphasized that the FRG Constitution, declaring the inviolability of dwelling, introduces a separate provision on the search to justify the possibility of limiting this law (if necessary): "(2) Searches may only be performed by a judge, and in cases of urgency by other statutory bodies but only in accordance with the law" (article 13).

As it can be seen from the above-mentioned definitions, the interpretation of the search essence has a lot in common in Russia and Germany.

\section{Causes to search}

Let us consider the causes to search as the most important aspect. Part 1, article 182 of the RFCCP names as the basis for the search (regardless of its type) "the availability of sufficient data to understand that some place or a person has weapons, equipment or other means of committing a crime, things, documents and valuables which may be of importance to the criminal case".

Not all scientists agree with the given definition. So, I.A. Misjuta believes that the word "data" is too vague and suggests using the term "evidence" instead [7]. However, we respectfully disagree with the author since "evidence" presupposes a certain result obtained, a kind of confirmation. And in the case of a search warrant, there can be just a guess (although there may be something confirmed) which can become evidence after the search.

S.A. Shaefer says that the actual causes to search include a set of data that allows us to make a substantiated assumption about the location of the objects under search. Accurate (reliable) data about this are not required by the law. Data supporting the decision to search include available evidence [5].

FRG Code of Criminal Procedure distinguishes the causes to search depending on the subject who is under search:

1) search of things and premises of the accused allows more mild causes: the presence of "simple" primary apprehension is sufficient; if there are causes to assume that the premises can house the evidence, there are no strict requirements imposed ( $§ 103)$;

2) search of other people suggests a more "strict" cause. Assumptions are not enough, there should be facts that can help to conclude that the searched person, the traces of the crime or the objects are in the room where the search is going to be conducted ( $§ 103)$;

3) search of the suspect - the cause includes apprehension, assumption that the suspect is a performer or a participant of the criminal act, or an accomplice, or hinders the application of justice, or is suspected of concealing (§ 102).

So, comparing such aspect of the studied concept as causes to search, it is possible to draw the following conclusion. The Russian Federation Code of Criminal Procedure contains the general formulation of the causes regardless of the type of search. FRG Code of Criminal Procedure, on the contrary, distinguishes between the causes of the (primary) assumptions and specific facts.

In this case, there is a distinction of the status of the subject: an accused, a suspect, or another person. Thereby a cautious approach to the personal scope is demonstrated (only "suspect" or "defendant"), this is quite understandable through a long historical tradition of protecting private property and privacy.

\section{The concept "dwelling" and approaches to its definition}

The above-considered causes can also be applied to the search of dwellings. The very concept of dwelling is defined in the Russian Federation Code of Criminal Procedure as follows: "dwelling is an individual house with its residential and non-residential premises, living premises regardless of ownership form which is included in the housing fund and used for permanent or temporary residence, or any other equal premise or a building that is not included in the housing fund but is used for temporary residence" (provision 10, article 5).

In the German criminal procedure provides this definition not inside the text of the Code of Criminal Procedure, but through the judicial decisions of relevant federal courts or land courts. Here are the most commonly used definition in the legal literature: premises which are really occupied by the suspect, and it does not matter whether it is lawful or unlawful, whether he is the sole owner or a co-owner and whether the right to privacy of premises can be applied to him [8], [9].

And it is usually emphasized that the concept "dwelling" should be, in accordance with the Constitution of the Federal Republic of Germany, interpreted broadly; in particular, this concept can also include not only private housing, but also office premises, manufacturing facilities, auxiliaries, hospital rooms, and rooms used solely or together on a provisional base (auxiliaries, hotel rooms), auto-campers and caravan-campers, but not cars themselves. A search warrant for the resident of the apartment, which is shared by a group of residents, does not mean the search of rooms of other residents that are not under suspicions; the concept "dwelling" in this case should be spread only 
to the living area of the certain suspect. Squatters (those who illegally took control of the house) are also subject to $\S 102$ of the FRG Code of Criminal Procedure in the case when they use these premises for a long time [8]. Thus, in light of tradition and nation-specific understanding of the property (including real estate), the definition of dwelling in Germany is broader in sense.

As a formal cause to search of the house there can be named the following:

according to the Russian Federation Code of Criminal Procedure - judicial decision (provision 5, part 2, article 29), in exceptional cases of urgency the resolution of the investigator or the detective without a judicial decision (paragraph 5, article 165); according to the FRG Code of Criminal Procedure - a judicial decision, and in cases of urgency the resolution of the Prosecutor's office and officials engaged in the investigation on behalf of the prosecution ((1) $\S 105)$. In this case, there are some differences; particularly a large role of the Prosecutor is noticeable in decision-making in the criminal procedure of Germany.

\section{Cases of urgency}

We would like to dwell on such concept as the case of urgency. Neither the Russian Federation Code of Criminal Procedure nor the FRG Code of Criminal Procedure provides explanations to such cases. However, the RFCCP in its provision 19, article 5 provides a definition of urgent investigative actions which assume actions undertaken after the initiation of criminal proceedings for the purposes of locating and fixing traces of the crime, and evidence that requires immediate fixing, withdrawal and research. In the Russian language the terms "urgent" and "exigent" are synonyms [10], [11], [12].

The German legislation does not contain an enumeration of cases that cannot afford delay, but there is their interpretation. In Germany, as it is known, there exists the land law which relies on federal legislation (but at the same time clarifies it). The Police Act of Bremen provides the following definition of urgent cases: "this is a situation in which the consequences of a dangerous situation have already begun to emerge (lit.: "adverse event") or will certainty begin as soon as possible" (provision 3 (b), § 2) [13].

The common aspect in the following interpretations for the both compared countries is the presence of a certain specific immediate danger or threat.

During the search of a dwelling in terms of legislation, there is also determined the list of the participants. In the Russian criminal process the participant can be the person whose premises is being searched (there also may come the defender or the lawyer of the person whose premises are searched), or an adult member of his family (provision 11, article 182, the Code of Criminal Procedure), mandatory participants - witnesses (provision 1, article 170, the Code of Criminal Procedure); there may be involved the officers of the investigation department (provision 7, article 164, the Code of Criminal Procedure). The Russian
Federation Code of Criminal Procedure does not regulate the question of how to hold the case without the person, whose premises are searched, or an adult member of his family. In practice, the officers are usually guided by the old regulation of the RSFSR Code of Criminal Procedure (1960), according to which in this case there should be a representative of the property management agency, village or township administration.

In the German criminal procedure the participants of the search of dwelling include the judge or the prosecutor, if they are absent - the officials (if possible) or two members of the community that occupy the territory being searched (they should not be police officers or individuals holding the investigation on behalf of prosecution) $((2) \S 105)$; the owner of the premises may be present, in case of his absence his representative or an adult member of his family, fellow living together, or a neighbour should be (if possible) attracted ((1) § 106).

Thus, the list of participants differs, though the German criminal procedure is less imperative.

Special attention is given to such aspect of the search of dwelling as the time of holding the search.

The FRG Code of Criminal Procedure has a separate article (§ 104) which prohibits searches of dwelling at night, except for the following cases (however, this does not apply to premises which are accessible at night): 1) hot-pursuit, 2) in cases of urgency, 3) to re-arrest a prisoner who escaped from the prison. The night period is defined as the period of time from 9 p.m. to 4 a.m. from April, 1 to September, 30; as the period of time from 9 p.m. to 6 a.m. from on October, 1 to March, 31 (§ 104).

In the Russian Federation Code of Criminal Procedure there is no specific article in relation to night searches. However, within article 164 embodying general rules of conducting investigative actions, we find provision 3 indicating that the performance of an investigative act is not allowed at night except in urgent cases. The night time is determined independently from the summer/winter period as "the period of time from 22 to 6 o'clock, local time" (provision 21, article 5, RFCCP).

\section{Conclusion}

So, we considered the procedural action - the search of dwelling which is, as we have already noted, the invasion of personal space and, accordingly, the undisputed fact of limiting his rights and freedoms. Therefore, this action requires special care and, consequently, further theoretical analysis. Let us consider our own proposals.

1. Special attention should be given to the causes of holding this investigative action. In this regard, it is possible to take into consideration the experience of Germany in terms of the status of the subject, whose dwelling is being searched, and in terms of the cause "enough evidence to suppose" to distinguish between "enough primary assumptions to suppose" (for the accused) and "enough detailed facts to suppose" (for a 
suspect). This distinction will more clearly define the degree of restriction of personal rights and freedoms.

2. The domestic judicial practice witnesses a large number of cases under article 182 of the Russian Federation Code of Criminal Procedure (see lawgoverned websites "Judicial and regulatory acts of the Russian Federation" and "RosPravosudie"). Here is an example: the applicant (name) appealed to the Central district court of Volgograd with the complaint, where she pointed to violations of the search of her apartment, in particular, the absence of a lawyer during the search, the failure of the official bodies to provide the proposal to surrender goods liable to seizure before the search, the presence of children, etc. [14], [15]. There could be quite a lot of similar examples that say about the appropriateness to elaborate the theory.

In the criminal procedure of Germany, the points under study are elaborated and specified at the level of the land legislation (we already spoke about the peculiarities of the German legislation -federal and land), but Russia has a different legal system. Therefore we offer:

1) regarding the list of the participants of the reviewing investigative actions - to complete the relevant article of the Russian Federation Code of Criminal Procedure with a provision on what, exactly, should guide the officers in case of absence of the person whose dwelling is searched, or an adult member of his family, or a lawyer;

2) to focus separately on awareness of the person who undergoes the search. As practice shows, it often happens that this person knows nothing about his rights and responsibilities;

3) to specify the regulation for cases of urgency which is mentioned by many legal scholars, because there are frequent abuses in this sphere in practice. For example, in January 2018 at a press conference, the Chairman of the Naberezhnochelninsky city court Rinat Gaifutdinov noted that law enforcement officers conducted more than 500 searches without a court order last year, and not all of them were recognized as legitimate, here is the quote: "We are fighting with this. The law says that carrying out a search in a dwelling is in itself an exceptional situation. Therefore, it stipulates that the search may only be conducted on the basis of a judicial decision. And without it, only exceptional cases could become the cause. We constantly raise this question at all meetings" [16], [17].

We believe: it would be appropriate under the Russian Federation Code of Criminal Procedure to qualify the cases in a more detailed way, although, of course, there are certain difficulties because it is not possible to list all such cases in each specific situation; however, you can give a description through defining characteristics (information received on the specific risk of occurrence of something or a threat, etc.).

The proposed measures will largely contribute to further improvement of national legislation, a more consistent adherence to the principle of protecting rights and freedoms of the individual.

\section{References}

1. A.V. Smirnov, K.B. Kalinowski, Criminal procedure: Textbook for universities (SPb.: $\mathrm{PH}$ "Peter", 2014)

2. A.F. Koni, Selected works in 2 volumes 1, 568-608 (1967)

3. L.V. Mayorova, Preface to the Russian edition, Criminal procedural law of the FRG (Krasnoyarsk: RUMC South Ossetia, 2004)

4. N. Davis, O. Ergunova, V. Lizunkov, E. Malushko, European Proceedings of Social and Behavioural Sciences 26, 550-556 (2017)

5. S.A. Schaefer, Investigative actions, Criminal procedure: tutorial for bachelors (M: Norma: INFRA-M, 2015)

6. Werner Beulke, Criminal procedural law of FRG: Textbook (Krasnoyarsk: RUMC South Ossetia, 2004)

7. I.A. Misjuta, Criminalist Library. Scientific journal 3 (20), 328-332 (2015)

8. Björn Gercke, Karl-Peter Julius, Heiko Ahlbrecht, Jürgen Brauer, Hans-Joachim Kurth, Strafprozessordnung (C.F. Müller GmbH, 2012)

9. M.A. Suzdalova, V.G. Lizunkov, E.Yu. Malushko, N.A. Sytina, V.E. Medvedev, The European Proceedings of Social \& Behavioural Sciences EpSBS XIX, 450-455 (2017)

10. Dictionary of Russian synonyms and expressions with similar sense (Moscow: Russian dictionaries, 1999)

11. E. Korobova, I. Kardovich, D. Mironova, M. Konysheva, Advances in Social Science Education and Humanities Research (ASSEHR) 97, 119-124 (2017)

12. E.V. Murugova, Vestnik Volgogradskogo Gosudarstvennogo Universiteta-seriya 2yazykoznanie 16 (2), 197-200 (2017)

13. Bremisches Polizeigesetz, URL: https://www.transparenz.bremen.de/sixcms/detail.ph p?gsid=bremen2014_tp.c.69192.de\&template=20_g p_ifg_meta_detail_d (date of access: 27.02.2018)

14. Appellate resolution No. $22 K-423 / 2015$ dated 2015, 4 February in the case No. $22 K-423 / 2015$, Judicial and regulatory acts of Russia (2015), URL: http://sudact.ru/regular/doc/K26uDP9TWGJm/ (date of access: 28.02.2018)

15. N.L. Shamne, E.V. Shishkina, Vestnik Volgogradskogo Gosudarstvennogo Universitetaseriya 2-yazykoznanie 16 (2), 143-151 (2017)

16. R. Gaifutdinov, Search of dwelling without a court order is an exceptional case, "BUSINESS Online": business electronic newspaper of Tatarstan, URL: https://www.business-gazeta.ru/article/370022 (date of access: 28.02.2018)

17. M.V. Konysheva, Materials of the International Scientific Conference on "Import substitution policy and development of non-resource export as the 
priority of today's industrial policy of Russian

Federation. Conference proceedings", 159-167

(Plekhanov Russian University of Economics,

Moscow, 2016) 